\title{
Antidiabetic effect of novel modulating peptides of G-protein-coupled kinase in experimental models of diabetes
}

\author{
Y. Anis ${ }^{1}$ O. Leshem ${ }^{1}$ H. Reuveni ${ }^{1}$ I. Wexler ${ }^{1,3} \cdot$ R. Ben Sasson ${ }^{2}$ B. Yahalom ${ }^{1}$ M. Master ${ }^{1}$ I. Raz Ra $^{2}$ \\ S. Ben Sasson ${ }^{4}$ E. Shafrir ${ }^{2}$ E. Ziv ${ }^{2}$ \\ ${ }^{1}$ Keryx Biopharmaceuticals, Jerusalem, Israel \\ 2 Diabetes Research Center, Department of Medicine, Hadassah University Hospital, Jerusalem, Israel \\ ${ }^{3}$ Department of Pediatrics, Hadassah University Hospital, Jerusalem, Israel \\ ${ }^{4}$ Department of Experimental Medicine \& Cancer Research, Hebrew University-Hadassah Medical School, Jerusalem, Israel
}

\section{Abstract}

Aims/hypothesis. G-protein-coupled receptor kinases (GRKs) play a key role in agonist-induced desensitisation of G-protein-coupled receptors (GPCRs) that are involved in metabolic regulation and glucose homeostasis. Our aim was to examine whether small peptides derived from the catalytic domain of GRK2 and -3 would ameliorate Type 2 diabetes in three separate animal models of diabetes.

Methods. Synthetic peptides derived from a kinasesubstrate interaction site in GRK2/3 were initially screened for their effect on in vitro melanogenesis, a GRK-mediated process. The most effective peptides were administered intraperitoneally, utilising a variety of dosing regimens, to Psammomys obesus gerbils, Zucker diabetic fatty (ZDF) rats, or $d b / d b$ mice. The metabolic effects of these peptides were assessed by measuring fasting and fed blood glucose levels and glucose tolerance.

Results. Two peptides, KRX-683 $3_{107}$ and KRX-683 124 , significantly reduced fed-state blood glucose levels in the diabetic Psammomys obesus. In animals treated with KRX-683 124 at a dose of $12.5 \mathrm{mg} / \mathrm{kg}$ weekly for 7 weeks, ten of eleven treated animals responded with mean blood glucose significantly lower than controls $(4.7 \pm 0.4$ vs $16.8 \pm 0.8 \mathrm{mmol} / \mathrm{l}, p \leq 0.0001)$. Significant reductions in blood glucose compared with controls were also seen in ZDF rats administered KRX-683 124 and in $d b / d b$ mice, which had significantly reduced fasting and 2-hour postprandial glucose levels after the treatment. Conclusions/interpretation. Sequence-based peptides derived from GRK2/3 have an antidiabetic effect demonstrated in three different animal models of Type 2 diabetes. By modulating GRK2/3 activity, these peptides enhance GPCR-initiated signal transduction, resulting in improved glucose homeostasis. Sequencebased peptide modulation of GRK could prove useful in the treatment of Type 2 diabetes.

Keywords $D b / d b$ mice - G-protein-coupled receptor · G-protein-coupled receptor kinase · Insulin resistance - Psammomys obesus - Type 2 diabetes . ZDF rats
Received: 15 December 2003 / Accepted: 19 April 2004 Published online: 3 July 2004

(C) Springer-Verlag 2004

E. Ziv (

Diabetes Research Center, Department of Medicine, Hadassah University Hospital, Jerusalem 91120, Israel E-mail: ehud@hadassah.org.il

Tel.: +972-2-6777558, Fax: +972-2-6418186

Abbreviations: GPCR, G-protein-coupled receptor * GRK, G-protein-coupled receptor kinases · MCR, melanocortin receptor $\cdot$ PBS-A, PBS containing BSA $0.5 \% \cdot \mathrm{PKC}$, protein kinase $\mathrm{C}$

\section{Introduction}

Type 2 diabetes is characterised by insulin resistance, impaired insulin secretion by pancreatic beta cells, and hyperglycaemia. Many forms of Type 2 diabetes are part of a potentially reversible metabolic syndrome that is associated with obesity, dyslipidaemia, hypertension, hypercoagulability, and vascular disease [1]. The causes of Type 2 diabetes have not been fully elucidated, and multiple genetic defects have been associated with the diabetic state $[2,3]$.

A potential way of treating Type 2 diabetes would be to target specific mechanisms leading to a reduction 
or abolishment of insulin resistance. Among emerging therapy concepts is stimulation of the G-protein-coupled receptors (GPCRs) associated with Type 2 diabetes, including adrenergic receptors, incretins, and the central melanocortin system $[4,5,6]$. Epidemiological studies have shown that polymorphisms of the $\beta 2$-adrenergic receptor are associated with diabetes [7, 8]. Additional GPCR targets modulating insulin dynamics include glucose-dependent insulinotropic polypeptide, other incretins, and the GPCR central melanocortin receptors (MCRs) that have been linked to abnormal appetite regulation and dysregulated lipid and/or glucose metabolism $[6,9,10]$.

A strategy for enhancing metabolism-related GPCR signalling is to prevent receptor desensitisation. Gprotein-coupled receptor kinases (GRK) down-regulate signal transduction initiated by GPCRs via phosphorylation of specific sites located on the receptors $[11,12,13,14]$. Inhibition of GRK-mediated GPCR desensitisation prolongs receptor activation, resulting in increased ligand-induced GPCR activity. GRK2 plays a major role in the agonist-specific desensitisation of several metabolism-related GPCRs, including the $\beta$-adrenergic receptor $[7,8,9]$, MCRs, endothelin, and glucose-dependent insulinotropic polypeptide [9, $11,15,16]$. By interfering with the interaction between GRK2 and its related GPCRs, GRK2 inhibition may restore glucose homeostasis and insulin sensitivity in Type 2 diabetes.

Sequence-based inhibition has been used to modulate the enzymatic activity of GRK2. Utilising a peptide corresponding to the C-terminus of GRK2, several groups have shown that the activities of the $\beta$-adrenergic and parathyroid hormone receptors are increased due to endogenous GRK2 inhibition [17, 18]. In previous studies, we have found that small sequence-based peptides taken from a loop (hereafter the HJ loop) that encompasses parts of $\alpha$ helix F and $\alpha$ helix G (subdomains IX-X located in the catalytic domain of the kinase) interfere with kinase-substrate binding among several protein kinases, leading to a decrease in substrate phosphorylation [19].

In this study, short peptides that closely resemble the HJ loop of GRK2/3 were synthesised. The effect of these peptides on glucose regulation in experimental models of Type 2 diabetes was subsequently assessed. Our results indicate that peptide inhibitors derived from the HJ loop of GRK2/3 have a positive effect on glucose metabolism in models of Type 2 diabetes.

\section{Materials and methods}

Reagents and peptides

Unless otherwise specified, all chemicals and reagents were purchased from Sigma (Rehovoth, Israel) and CalBiochem (Darmstadt, Germany). The B16F1 murine cells (CRL-6323) used for the melanogenesis assay were obtained from American
Type Culture Collection (Manassas, Va., USA). The peptides, listed in Table 1, were synthesised commercially (Novetide, Haifa, Jerusalem, Israel or Multiple Peptide Systems, San Diego, Calif., USA) using FMOC solid phase technology. Peptides were purified by the manufacturer using reverse-phase HPLC. For initial screening, the purity of the peptides was greater than $80 \%$. The peptides KRX-683 107 and KRX-683 124 , which were extensively studied in animals, were prepared as acetate salts with a purity of more than $98 \%$. Peptides were stored as a powder at $4{ }^{\circ} \mathrm{C}$ until immediately prior to use when they were dissolved in specific formulations. For initial screening and melanogenesis assays, peptides were dissolved in an SHS formulation (described below).

For animal studies, specific formulations for KRX-683 107 and KRX-683 124 were utilised. The formulations were designed to optimise solubility of the peptides in biological fluids. KRX$683_{107}$ was administered in a TBI formulation prepared as follows: the peptide was dissolved in DMSO (8\% final concentration), and $2 \mathrm{~mol} / \mathrm{l}$ ammonium bicarbonate (32\% v/v). The mixture was boiled for $40 \mathrm{~min}$, after which $2 \mathrm{~mol} / \mathrm{l}$ HEPES buffer (Sigma-Aldrich, St. Louis, Mo., USA), pH 7.5 (60\% v/v) were added. KRX-683 124 was formulated in SHS as follows. The peptide was first dissolved in DMSO (4\% v/v). To this solution, glycerol $(6 \% \mathrm{w} / \mathrm{v})$ and Solutol HS 15 (BASF, Ludwigshafen, Germany) (1.8\% w/v) were added. The same formulation was used for KRX-683 107 in the melanogenesis assays. The peptides, once formulated, were stored at $4{ }^{\circ} \mathrm{C}$ until use.

\section{Melanogenesis assay}

Previously described methods for measuring in vitro melanogenesis using a B16F1 murine melanoma cell line were used [20]. B16F1 cells were grown in DMEM supplemented with L-glutamine $2 \mathrm{mmol} / \mathrm{l}$, glucose $4.5 \mathrm{~g} / \mathrm{l}$, fetal calf serum $10 \%$, penicillin 100 units $/ \mathrm{ml}$ and streptomycin $0.1 \mathrm{mg} / \mathrm{ml}$ (Biologocial Industries, Bet HaEmek, Israel) and incubated in a $5 \% \mathrm{CO}_{2}$ humidified environment. We seeded 96-well plates with approximately 5000 cells per well and incubated them for $24 \mathrm{~h}$ prior to melanogenesis induction. For melanogenesis induction, serial dilutions ranging from $25 \mu \mathrm{mol} / 1$ to $0.15 \mu \mathrm{mol} / \mathrm{l}$ of each peptide tested were prepared from stock solutions using PBS $0.1 \%$ BSA and subsequently diluted $1: 10$ in the B16F1 cell cultures.

NDP- $\alpha$ MSH $0.5 \mathrm{~mol} / \mathrm{l}$ (Sigma, Rehevoth, Israel) in $16 \%$ acetic acid was further diluted with the culture medium to final concentrations ranging from 6 to $50 \mathrm{pmol} / \mathrm{l}$. NDP- $\alpha \mathrm{MSH}$ was added to B16F1 cells at the same time as the tested peptides. Cells were lysed after 4 days with $70 \mu \mathrm{l} 1 \mathrm{~N} \mathrm{NaOH}$, and melanin was measured by optical density at a wavelength of $405 \mathrm{~nm}$ using an ELX 800 (Bio-Tek, Winooski, Vt., USA) ELISA reader. Assays were done in six replicates and the results averaged. Cells with medium containing no peptide and/or NDP- $\alpha$ MSH were used as blanks.

The protein kinase inhibitors AG1478, Genistein, GF109203X, LY294002 and PD169316 were obtained from CalBiochem. The final concentration of these inhibitors in cell culture was $10 \mu \mathrm{mol} / \mathrm{l}$ except for Genistein, which was $30 \mu \mathrm{mol} / \mathrm{l}$. Inhibitors were added together with either $\operatorname{KRX} 683_{124}(2.5 \mu \mathrm{mol} / \mathrm{l})$ or NDP- $\alpha \mathrm{MSH}(0.1 \mathrm{nmol} / \mathrm{l})$. The melanogenesis assays were performed as described above.

Intracellular uptake assay

B16F1 melanoma cells were grown in the same culture medium as used for melanogenesis, and then seeded into each chamber of a 4-chamber slide at a concentration of 30,000 
Table 1. Synthetic GRK-683 peptides derived from GRK 2/3 and their relative activity

\begin{tabular}{|c|c|c|c|c|c|c|c|c|c|c|c|c|c|c|}
\hline \multirow[t]{2}{*}{ Peptide } & \multicolumn{12}{|l|}{ Sequence } & \multirow[t]{2}{*}{$\mathrm{OD}_{\max }$} & \multirow[t]{2}{*}{$\mathrm{EC}_{50}$} \\
\hline & Fatty acid & & & $\mathrm{L}_{384}$ & $\mathrm{~L}$ & $\mathrm{R}$ & G & $\mathrm{H}$ & $S$ & $\mathrm{P}_{390}$ & $\mathrm{~F}$ & & & \\
\hline KRX-683 103 & Myristyl & G & & $\mathrm{L}$ & $\mathrm{L}$ & $\mathrm{R}$ & $\mathrm{k}$ & $\mathrm{H}$ & $\mathrm{S}$ & & & $\mathrm{NH}_{2}$ & 0.7 & 0.4 \\
\hline KRX-683 ${ }_{162}$ & Myristyl & G & & $\mathrm{L}$ & $\mathrm{L}$ & $\mathrm{R}$ & $\mathrm{K}$ & $\mathrm{H}$ & $\mathrm{S}$ & & & $\mathrm{NH}_{2}^{2}$ & 0 & - \\
\hline KRX-683 109 & Myristyl & G & & $\mathrm{L}$ & $\mathrm{L}$ & $\mathrm{R}$ & $\mathrm{k}$ & $\mathrm{H}$ & $\mathrm{S}$ & $\mathrm{P}$ & & $\mathrm{NH}_{2}^{2}$ & 0.18 & - \\
\hline KRX-683 107 & Myristyl & G & & $\mathrm{L}$ & $\mathrm{L}$ & $\mathrm{R}$ & $\mathrm{r}$ & $\mathrm{H}$ & $\mathrm{S}$ & & & $\mathrm{NH}_{2}^{2}$ & 0.79 & 0.42 \\
\hline KRX-683 & Myristyl & G & & $\mathrm{L}$ & $\mathrm{L}$ & $\mathrm{R}$ & $\mathrm{r}$ & $\mathrm{H}$ & $\mathrm{S}$ & I & & $\mathrm{NH}_{2}^{2}$ & 0.8 & 0.4 \\
\hline KRX-683 & Stearyl & G & & $\mathrm{L}$ & $\mathrm{L}$ & $\mathrm{R}$ & $\mathrm{r}$ & $\mathrm{H}$ & $\mathrm{S}$ & I & & $\mathrm{NH}_{2}^{2}$ & 0 & - \\
\hline KRX-683 & Lauryl & G & & $\mathrm{L}$ & $\mathrm{L}$ & $\mathrm{R}$ & $\mathrm{r}$ & $\mathrm{H}$ & S & I & & $\mathrm{NH}_{2}$ & 0.8 & 0.3 \\
\hline KRX-683 108 & Myristyl & G & & $\mathrm{L}$ & $\mathrm{L}$ & $\mathrm{R}$ & $\mathrm{r}$ & $\mathrm{H}$ & $\mathrm{S}$ & $\mathrm{K}^{\mathrm{a}}$ & & $\mathrm{NH}_{2}$ & 0.74 & 0.56 \\
\hline KRX-123 302 & Myristyl & G & $\mathrm{L}$ & $\mathrm{V}$ & $\mathrm{T}$ & $\mathrm{Y}^{\mathrm{c}}$ & $\mathrm{k}$ & $\mathrm{K}$ & I & $\mathrm{K}^{\mathrm{b}}$ & & $\mathrm{NH}_{2}^{2}$ & 0 & - \\
\hline KRX-702 $2_{105}$ & Myristyl & G & & $\mathrm{R}$ & A & G & $\mathrm{N}$ & Q & Y & $\mathrm{L}$ & & $\mathrm{NH}_{2}^{2}$ & 0 & - \\
\hline
\end{tabular}

Amino acid residues in lower case are dextrorotary enantiomers. ${ }^{a}$ Biotinylated lysine; ${ }^{\mathrm{b}} \mathrm{Ne}$ (benzylamide)lysine; ${ }^{\mathrm{c}} 3,5$-diiodo-tyrosine; $\mathrm{EC}_{50}$, median effective concentration; $\mathrm{OD}_{\max }$, optimum maximum dose

cells/ml (21,600 cells/well) for $24 \mathrm{~h}$. Biotinylated KRX-683 108 $(10 \mathrm{mmol} / \mathrm{l})$ was dissolved in a solution containing DMSO $10 \%, \mathrm{NaSCN} 45 \%$, and n-butanol $45 \%$. This solution was further diluted 1:1000 in culture media to a final peptide concentration of $10 \mu \mathrm{mol} / \mathrm{l}$, and incubated with B16F1 cells for $3 \mathrm{~h}$. The cells were washed three times with PBS containing BSA $0.5 \%$ (PBS-A), and then fixed with $4 \%$ paraformaldehyde in PBS for $20 \mathrm{~min}$ at room temperature. Cells were permeabilised by incubating them for $20 \mathrm{~min}$ in a solution of $0.2 \%$ Triton X100 and PBS-A. Cells were again washed three times with PBS-A and incubated with a 1:1000 dilution of Avidin-FITC in PBS-A. Slide wells were covered with a special cover slip (Vectashield, Vector Laboratory, Burlingame, Calif., USA) and then visualised with a confocal fluorescent microscope to determine intracellular fluorescence. Photo-documentation was done by digital imaging. As controls, incubation medium without peptide and a non-biotinylated peptide with the same sequence as KRX-683 107 were utilised (Table 1). Experiments were done in duplicate.

\section{Selection of KRX-68, a modulator of GRK2/3 signalling}

Short peptides resembling a segment of the HJ loop sequence, a potential kinase-substrate interaction region located between amino acids 384-389 of GRK2/3, were synthesised (Table 1). All peptides had a glycine attached to a fatty acid moiety added to the N-terminus to facilitate intracellular penetration (Fig. 1). In order to quantify the effect of a putative GRK2/3 modulator at the cellular level, we used the MSH receptors system, a GPCR family that mediates the induction of pigmentation in the periphery and controls energy homeostasis in the central nervous system. Melanocytic melanin production is stimulated by MSH and other proteins in the melanogenic transduction pathway. By inhibiting desensitisation of the $\mathrm{MSH}$ receptors, melanin accumulation is enhanced. The efficacy of GRK2/3-derived peptides was based on the level of melanin produced by B16F1 cells in the absence of exogenous NDP- $\alpha$ MSH.

In initial experiments, the glycine at position 387 was changed to D-lysine (KRX-683 103 and KRX-683 109 ). It was found that in cell-based assays the change to L-lysine enhanced the activity of peptides derived from the HJ loop, possibly by improving peptide stability (e.g., enzymatic proteolytic degradation), as there was minimal melanogenesis when L-lysine was substituted for D-lysine (Table 1, KRX-683 162 ). As shown in Table 1, KRX-683 $3_{103}$ stimulated significant melanogenesis $\left(\mathrm{EC}_{50}=0.4 \mu \mathrm{mol} / \mathrm{l}\right)$. When Pro390 was included in the peptide sequence, melanin production decreased, possibly due to conformational limitations introduced by the fixed structure of proline (KRX-683 109 ).

For subsequent peptide syntheses, D-arginine, another positively charged amino acid residue, was substituted for Gly387 with no loss of melanogenic activity (Table 1, peptides KRX$683_{107}, \mathrm{KRX}-683_{112}$, and KRX-683 124 ). The length of the fatty acid moiety was seen to have an effect, as there was a significant decrease in melanogenesis when a stearyl group was substituted for myristyl or lauryl (KRX-683 112 and KRX-683 ${ }_{124}$ vs KRX-683 912 ). To test for specificity, a myristoylated peptide targeting the same sequence in Lyn kinase (Table 1, KRX$123_{302}$ ) and an unrelated myristoylated peptide derived from the serine/threonine kinase PDK1 (Table 1, KRX-702 ${ }_{105}$ ) were evaluated for their effects on melanogenesis. Neither of these peptides had any biological effect.

\section{Animal models of diabetes}

To test the effect of KRX peptides in a wide spectrum of syndromes similar to Type 2 diabetes, we used three animal models. The gerbil Psammomys obesus is normoglycaemic without genetic mutation [21] but prone to insulin resistance and diabetes on a high-energy diet. Zucker diabetic fatty (ZDF) rats are devoid of leptin receptor, obese, hyperglycaemic and hyperlipidaemic in their basal state. The other animal model used, $d b / d b$ mice, is also devoid of leptin receptor and highly insulin-resistant. Specific experimental protocols are described in the Results. Dosages and frequency of administration were established after initial pilot studies. All experimental procedures were approved by the Hebrew University-Hadassah Medical School Institutional Animal Care Committee. All animals had free access to water and food.

Psammomys obesus. Female Psammomys gerbils were bred at the Hebrew University-Hadassah Medical School Animal Farm and housed in individual polypropylene cages. Animals from the diabetes-prone line [22] were weaned at 3 weeks of age and started on a low-energy diet $(2.4 \mathrm{kcal} / \mathrm{g}, 16.7 \%$ protein; Koffolk, Petach Tikva, Israel). Animals were subsequently randomised to a high-energy diet $(3.0 \mathrm{kcal} / \mathrm{g}, 23.4 \%$ protein; Tekled Global, Madison, Wis., USA) or kept on the low-energy diet. Animals on the high-energy diet with blood glucose 

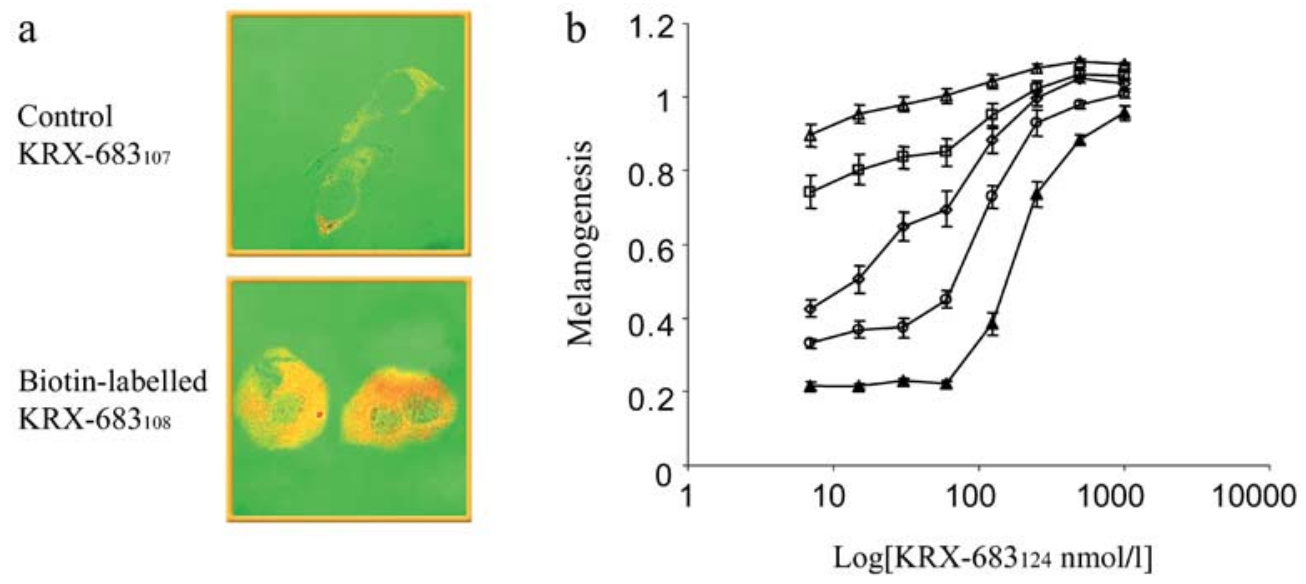

\begin{tabular}{|c|c|c|c|c|c|}
$\mathbf{C} \quad$ Kinase & Kinase inhibitor & KRX-683 & $\alpha M S H$ & Inhibitor + KRX-683 & Inhibitor $+\alpha M S H$ \\
\hline & & & & & \\
\hline EGFR & AG-1478 & 0.72 & 0.52 & 0.75 & 0.58 \\
\hline PTK & Genistein & 0.72 & 0.5 & 0.73 & 0.57 \\
\hline PKC & GF109203X & $\mathbf{0 . 7}$ & $\mathbf{0 . 5 4}$ & $\mathbf{0 . 0 5}$ & 0.01 \\
\hline P38 & PD169316 & 0.72 & 0.63 & 0.7 & 0.5 \\
\hline PI3K & LY294002 & 0.7 & 0.57 & 0.71 & 0.5 \\
\hline
\end{tabular}

Fig. 1. Intracellular penetration of KRX-683 and its effect on melanogenesis. a. B16F1 cells after $2 \mathrm{~h}$ incubation with biotinylated KRX-683 108 and staining with Avidin-FITC (top panel). The lower panel is a control for non-specific staining using non-biotinylated KRX-683. b. Melanin production (optical density) after incubating B16F1 cells for 3 days in various concentrations of KRX-683 124 and NDP- $\alpha \mathrm{MSH}$. Open triangle: $50 \mathrm{pmol} / \mathrm{l} \mathrm{MSH}$; open square: $25 \mathrm{pmol} / \mathrm{l} \mathrm{MSH}$; open diamond: $12.5 \mathrm{pmol} / \mathrm{l} \mathrm{MSH}$; open circle: $6 \mathrm{~mol} / \mathrm{l} \mathrm{MSH}$; closed triangle: $0 \mathrm{pmol} / \mathrm{l} \mathrm{MSH}$. c. Effect of protein kinase inhibitors on melanogenesis stimulated by KRX-683 124 and NDP- $\alpha$ MSH. B16F1 cells were incubated with a kinase inhibitor and either KRX$683_{124}(2.5 \mu \mathrm{mol} / 1)$ or NDP- $\alpha \mathrm{MSH}(0.1 \mathrm{nmol} / \mathrm{l})$ for 3 days

levels between 11.1 and $20 \mathrm{mmol} / \mathrm{l}$ during the course of a week (blood glucose levels tested at least three times) were included in the study.

Zucker diabetic fatty rats. Male homozygous ZDF rats were purchased from Charles River Laboratories (Wilmington, Mass., USA) and housed, two per cage, in polypropylene cages under specific pathogen-free conditions. The rats received a high-energy diet (same as for Psammomys). ZDF rats on the high-energy diet developed hyperglycaemia $(>11.1 \mathrm{mmol} / \mathrm{l})$ by 9 to 10 weeks of age [23].

C57 BL/Ks leprdb (db/db) mice. Male homozygous $d b / d b$ mice were purchased from Harlan, UK. The mice were housed five to ten per polypropylene cage under specific pathogen-free conditions and had free access to the high-energy diet. They developed hyperglycaemia $(>11.1 \mathrm{mmol} / \mathrm{l})$ by 12 to 15 weeks of age [24].

Animal treatments. All animals used in these experiments had their blood glucose and body weight monitored two to four times a week. They were injected intraperitoneally with either KRX-683 $3_{107}$ or KRX-683 124 at doses ranging from 5 to $10 \mathrm{mg} / \mathrm{kg}$ (see Results). The concentrations of the injected solutions were adjusted so that each Psammomys and ZDF rodent received $1 \mathrm{ml}$ per injection and each $d b / d b$ mouse $0.2 \mathrm{ml}$ per injection.
Glucose was determined on blood taken from the tail vein using Glucometer Elite (Bayer, Elkhart, Ind., USA). Animals on the high-energy diet were considered diabetic if their nonfasting blood glucose was greater than $200 \mathrm{mg} / \mathrm{dl}$. Triglycerides (fasting) were measured in $\mathrm{ZDF}$ rats one week before the end of the experiment using a commercial kit (Roche, Basel, Switzerland). Plasma insulin was radio-immunoassayed using anti-human insulin antibodies (DiaSorin, Saluggia, Italy) and human insulin as a standard.

Glucose tolerance tests were performed on animals after an overnight fast. Glucose at a dose of $1 \mathrm{~g} / \mathrm{kg}$ was dissolved in $1 \mathrm{ml}$ doubly distilled $\mathrm{H}_{2} \mathrm{O}$ and administered intraperitoneally to Psammomys and ZDF rats. For $d b / d b$ mice, $2 \mathrm{~g} / \mathrm{kg}$ dissolved in $0.3 \mathrm{ml}$ was injected. Blood glucose levels were monitored at 0 , $0.25,0.5,1,2$, and $3 \mathrm{~h}$ after injection. At the end of the experiment, the animals were anaesthetised by diethylether and bled to death by abdominal aortic puncture. Immediately after death, liver, heart, kidneys and epididymal or white superscapular fat tissues were excised and weighed.

\section{Statistical analysis}

All values are given as means \pm SE. Group comparisons were made by non-paired two-tailed Student's $t$ test . A $p$ value of 0.05 or less was considered significant. As the serum glucose values in $\mathrm{ZDF}$ rats at the beginning of the experiment were wide-ranging (11-22 nmol/l), the initial glucose levels at the onset of the experiment were normalised (100\%), and the percentage differences between initial glucose and final glucose at the end of the experiment were calculated for each animal.

\section{Results}

Preliminaries. Studies were done on KRX-683 124 to determine the relationship between concentration and effect using melanin production by $\mathrm{B} 16 \mathrm{~F} 1$ cells as a measure of efficacy. In the absence of NDP- $\alpha \mathrm{MSH}$, a classic concentration-response curve was generated 
Table 2. Effect of KRX-683 treatment on blood glucose and body weight in Psammomys obesus

\begin{tabular}{|c|c|c|c|c|c|c|}
\hline Cohort & $n$ & $\begin{array}{l}\text { Body weight } \\
\text { gain }(\mathrm{g})\end{array}$ & $\begin{array}{l}\text { Responding } \\
\text { animals, } n\end{array}$ & $\begin{array}{l}\text { Mean blood glucose } \\
\text { at start }(\mathrm{mmol} / \mathrm{l})\end{array}$ & $\begin{array}{l}\text { Mean blood glucose } \\
\text { at end }(\mathrm{mmol} / \mathrm{l})\end{array}$ & $\begin{array}{l}\text { Decrease in } \\
\text { glucose }(\%)\end{array}$ \\
\hline KRX-683 107 & 10 & $10 \pm 2$ & 6 & $19.2 \pm 0.6$ & $12.0 \pm 2.5$ & $39 *$ \\
\hline Non-responders & 4 & $12 \pm 2$ & & $20.7 \pm 0.7$ & $19.8 \pm 1.8$ & 4 \\
\hline TBI Vehicle & 12 & $19 \pm 1$ & 0 & $18.4 \pm 1.2$ & $17.8 \pm 0.9$ & 3 \\
\hline Non-treated & 5 & $14 \pm 2$ & 0 & $19.2 \pm 1.3$ & $20.0 \pm 2.1$ & -4 \\
\hline SHS Vehicle & 7 & $54 \pm 5^{b}$ & 0 & $17.6 \pm 0.7$ & $17.5 \pm 1.1$ & 0 \\
\hline
\end{tabular}

a One of the animals, which became insulinopaenic, was not included in the calculations. b These groups of animals were in a stage of rapid growth. $* p<0.05$ compared with vehicle-treated control animals

(Fig. 1a). When increasing concentrations of NDP$\alpha \mathrm{MSH}$ were added to the culture media, basal levels of melanogenesis increased as expected (Fig. 1b). Subsequent addition of KRX-683 124 increased melanin production in an additive manner with a decrease in the $\mathrm{EC}_{50}$. At high levels of NDP- $\alpha \mathrm{MSH}$, the effect of KRX-683 124 is diminished with only minimal increases in melanin production. The most potent peptides, KRX-683 124 and KRX-683 $3_{107}$, were selected for our further studies of the antidiabetic effect of a modulator of GRK2/3 signalling.

Protein kinase $C$ inhibition reverses the effect of $K R X-683$. To determine the signal transduction pathway that is involved in mediating the effect of KRX- $683_{124}$, a variety of specific kinase inhibitors were incubated in the presence of either KRX-683 124 or NDP- $\alpha$ MSH and the melanogenic response was measured. GF109203X, an inhibitor of protein kinase C (PKC), abolished melanogenesis stimulated by KRX- $683_{124}$ or NDP- $\alpha$ MSH (Fig. 1c). Taken together, the data indicate that $\mathrm{PKC}$ is required for KRX-683 124 and NDP- $\alpha \mathrm{MSH}$ to induce melanogenesis, and that the site of PKC signal transduction in melanogenesis is downstream of GRK2/3 and the MCR.

Effect of KRX-683 107 on hyperglycaemic Psammomys. To determine whether GRK2/3-derived peptides have an effect on Type 2 diabetes, we tested two of the more active peptides, KRX-683 $3_{107}$ and KRX-683 ${ }_{124}$. Diabetic Psammomys were administered KRX-683 ${ }_{107}$, $12.5 \mathrm{mg} / \mathrm{kg}$ i.p. for a period of 4 weeks (four injections). At the end of the treatment period, the average blood glucose of the KRX-683 107 -treated group had declined by $35 \%(p \leq 0.027)$ (Table 2$)$ in comparison with the vehicle-treated control group, in which the mean blood glucose level did not change during the treatment period. When individual animals were analysed, the animals clustered into one of two discrete groups as shown in Table 2 and Figure 2. A majority of diabetic animals (6 of 10;60\%) had a rapid drop (within first week) in blood glucose to near normal levels $(6.9 \mathrm{mmol} / \mathrm{l})$. The second subgroup (4 of 10 ; $40 \%$ ) did not respond throughout the trial and remained diabetic. The effect of this peptide appears to be specific, as none of the untreated animals (vehicle injection, unrelated peptide injection, or no treatment) had a reduction in blood glucose level (Fig. 2a, b). This experiment was repeated and identical response rates were obtained ( 6 of 11 treated vs 0 of 9 control animals after 3 weeks treatment).

The diabetic phenotype of Psammomys is associated with insulin resistance that is characterised by hyperinsulinaemic hyperglycaemia and an abnormal glucose tolerance profile. To test whether KRX-683 107 affected these parameters, we performed glucose tolerance tests before and after treatment with KRX-683 107 and measured non-fasting glucose levels. Prior to treatment, all diabetic animals had abnormal blood glucose levels after a glucose load, with an average blood glucose after $3 \mathrm{~h}$ of about $1.7 \mathrm{mmol} / \mathrm{l}$ for all animal groups. After treatment, the mean blood glucose of the animals treated with KRX- $683_{107}$ was significantly lower than that of the different control groups both at 2 and at 3 hours after the glucose load.

Analysis of individual animals in the vehicle-treated control group showed that seven out of ten had normal glucose levels after $3 \mathrm{~h}$ vs two out of ten of the vehicle-treated control and none of the animals of the other control groups. The same KRX-683 107 -treated animals with normal random glucose levels after four weekly injections also had normal results in a 3-h post-glucose load glucose tolerance test (Fig. 3a). With regard to insulin levels, six out of ten of the KRX $683_{107}$-treated animals had insulin levels similar to non-treated, non-diabetic controls (Fig. 3b).

To determine whether KRX-683 107 affects the obesity phenotype in Psammomys fed on the high-energy diet, the change in total weight during the course of the experiment and organ weights at the end of treatment were measured. Total weight gain in Psammomys during the weekly KRX-683 107 peptide administration compared with animals treated with the TBI vehicle is shown in Table 2. Weight gain was slower 

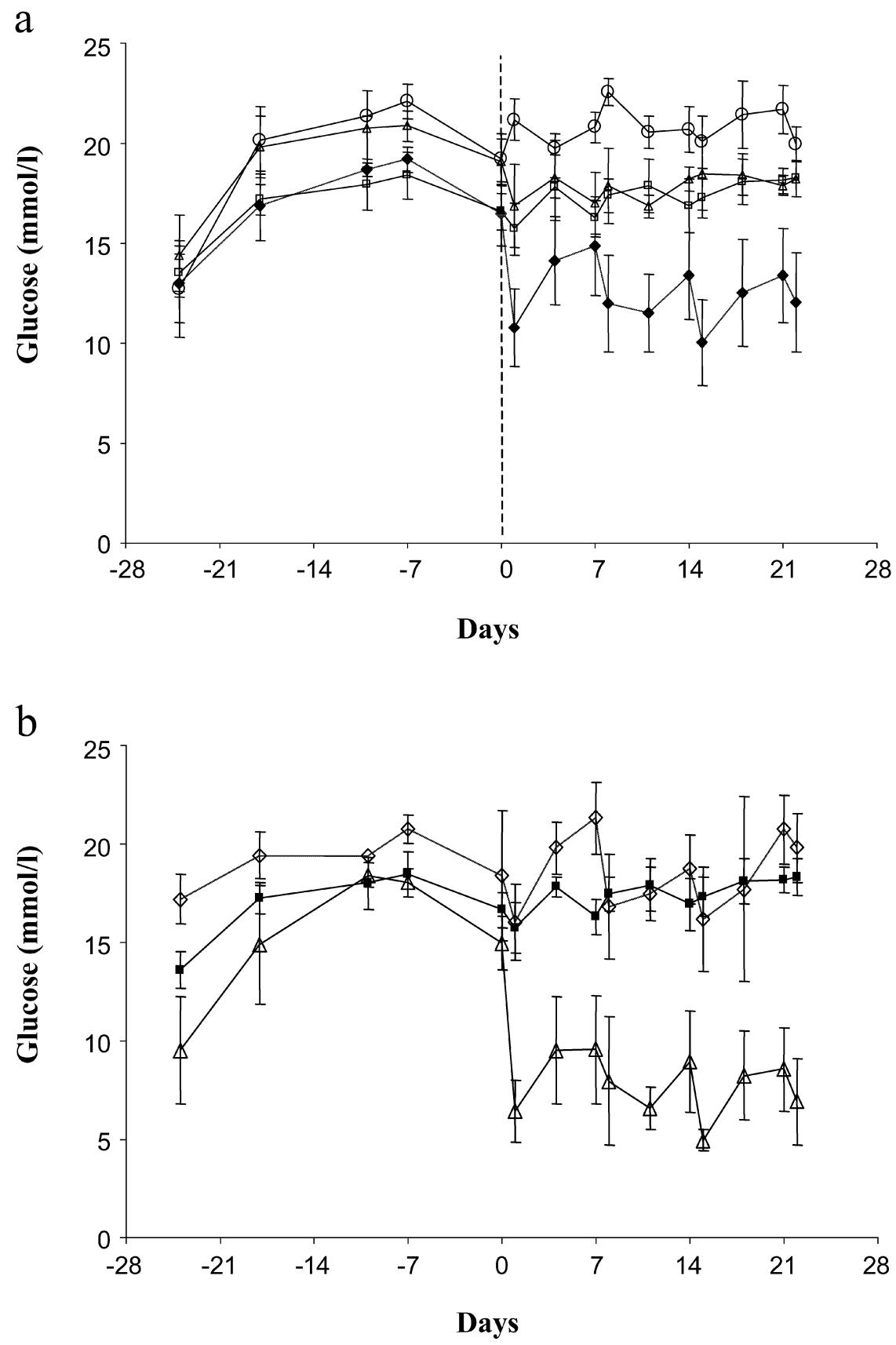

Fig. 2. KRX-683 107 reduces mean blood glucose level in diabetic Psammomys. a. Diabetic Psammomys treated with either four weekly injections of KRX-683 $3_{107} 12.5 \mathrm{mg} / \mathrm{kg}$ (filled diamond), vehicle control (open square), or an unrelated peptide

KRX-123 302 (open triangle). A fourth group received no treatment (open circle). b. KRX-683 107 responders (open triangle), non-responders (open diamond) vs control vehicle (filled square) during four weeks of treatment

Table 3. Adipose tissue weight (g) following KRX-683 treatment

\begin{tabular}{llllll}
\hline & \multicolumn{3}{l}{ Treatment } & & \\
\cline { 2 - 6 } Adipose tissue & KRX-683 124 & Control SHS & KRX-683 $_{107}$ & Control TBI & KRX-123 302 \\
\hline Psammomys, superscapular & $1.35 \pm 0.07^{\mathrm{a}}$ & $2.00 \pm 0.18$ & $1.58 \pm 0.16^{\mathrm{a}}$ & $2.11 \pm 0.11$ & $2.17 \pm 0.09$ \\
ZDF rats, epididymal & $2.34 \pm 0.12$ & $2.35 \pm 0.04$ & $2.16 \pm 0.30$ & $2.20 \pm 0.09$ & \\
db/db mice, superscapular & $5.16 \pm 0.50$ & $6.10 \pm 0.20$ & & &
\end{tabular}

a $p \leq 0.05$ compared with vehicle-treated controls 
a
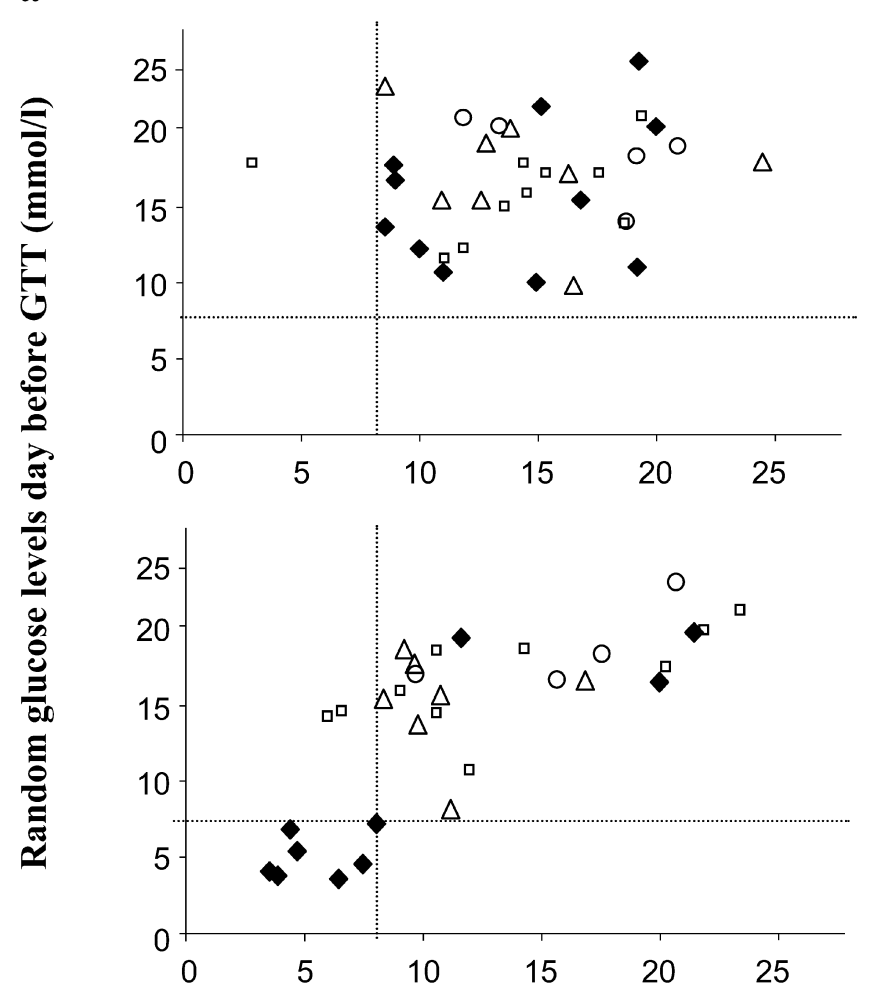

Glucose 3 h post GTT onset

b

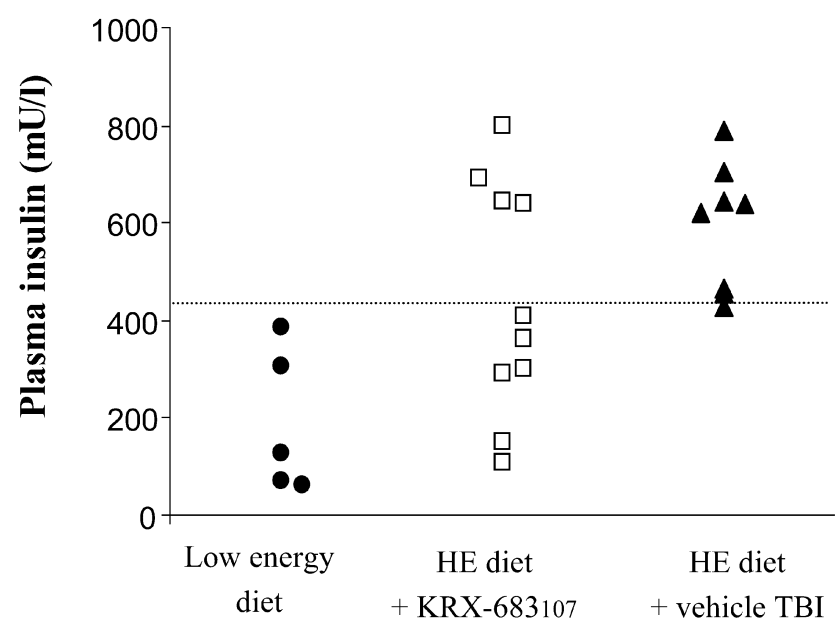

Fig. 3. Relationship (a) between random and 3-h glucose tolerance tests (GTT) in diabetic Psammomys before (above) and after four weeks of treatment with KRX-683 107 (below). Filled diamond: KRX-683 107 -treated animals $(n=11)$; open square: vehicle-treated animals $(n=10)$; open circle, non-treated animals $(n=5)$; open triangle: animals treated with the non-related peptide, KRX-123 302 . $(n=7)$. b. Insulin levels after treatment with KRX-683 107 in the fed state comparing KRX-683 107 -treated animals (open squares, high-energy diet, $n=10$ ) to vehicletreated diabetic animals (filled triangles, high-energy diet, $n=8$ ) and non-diabetic animals (filled circles, low-energy diet, $n=5$ ). The vertical and horizontal dotted lines represent the upper limit of normoinsulinaemic Psammomys in the fed state. $\mathrm{HE}$, high-energy in the KRX-683 107 -treated Psammomys during the experiment than in animals treated with vehicle. At the end of the experiment, the mean weight gain of the treated animals was $52 \%$ lower than that of controls $(p \leq 0.012)$. There was a significant decrease in the mean weight of the superscapular fat pad in the treated animals after treatment with KRX-683 ${ }_{107}$ (Table 3). There were no significant differences in the average weight of the heart, kidney and liver between the two groups (data not shown), indicating that the decrease in overall and fat pad weight in the treated group was not related to an anorectic effect of KRX-683 107 .

Effect of KRX-683 124 on hyperglycaemic Psammomys. Changing the amino acid and fatty acid composition of KRX-683 alters its physiochemical characteristics. To test whether these changes were also associated with a physiological effect on glucose homeostasis, we tested KRX-683 124 (which is one amino acid longer and has a shorter fatty acid moiety) in a similar way to the way that KRX-683 107 was tested. Psammomys on a high-energy diet received KRX-683 124 , $12.5 \mathrm{mg} / \mathrm{kg}$ once weekly or $6.25 \mathrm{mg} / \mathrm{kg}$ twice weekly for 7 weeks. As shown in Figure 4 and Table 2, there was a significant reduction in average non-fasting blood glucose in animals treated once weekly with $12.5 \mathrm{mg} / \mathrm{kg} \mathrm{KRX}-683_{124}$, as compared with pre-treatment glucose values $(4.7 \pm 0.4$ vs $16.8 \pm 0.8 \mathrm{mmol} / \mathrm{l}$, $p \leq 0.0001)$. The vehicle-treated group maintained the same mean blood glucose throughout the experiment. Of the eleven treated animals, ten had glucose values restored to near-normal, whereas $100 \%$ of the vehicle-treated group remained diabetic (mean glucose $17.5 \pm 1.1 \mathrm{mmol} / \mathrm{l}$ ). The single treated animal that did not respond had evidence of insulinopaenic diabetes (e.g. extreme weight loss, high fasting glucose). The hyperglycaemic response was less impressive in animals receiving $6.25 \mathrm{mg} / \mathrm{kg}$ twice weekly. Only four of nine treated animals responded, indicating that a higher dose, even when administered less frequently, was more effective (Fig. 4). The response to KRX-683 124 was not uniform as some animals responding promptly, and others did not respond until 4 to 6 weeks after treatment began.

Effect of KRX-683 peptides on hyperglycaemic ZDF rats. We tested whether KRX-683 124 is effective in treating other forms of experimental Type 2 diabetes in ZDF rats. The results of treatment of ZDF diabetic rats with KRX-683 124 are presented in Figure 5a. Blood glucose concentrations in untreated ZDF rats on a high-energy diet increased from a mean of $10 \mathrm{mmol} / \mathrm{l}$ at the age of 10 to 11 weeks to $16.7 \mathrm{mmol} / \mathrm{l}$ at the age of 17 to 18 weeks. Same-aged ZDF rats that received KRX-683 124 peptide for a period of 5 weeks at doses increasing from 10 to $30 \mathrm{mg} / \mathrm{kg}$ did not show the same increase (Fig. 5a). As glucose levels in these animals at the start of the experiment were markedly 

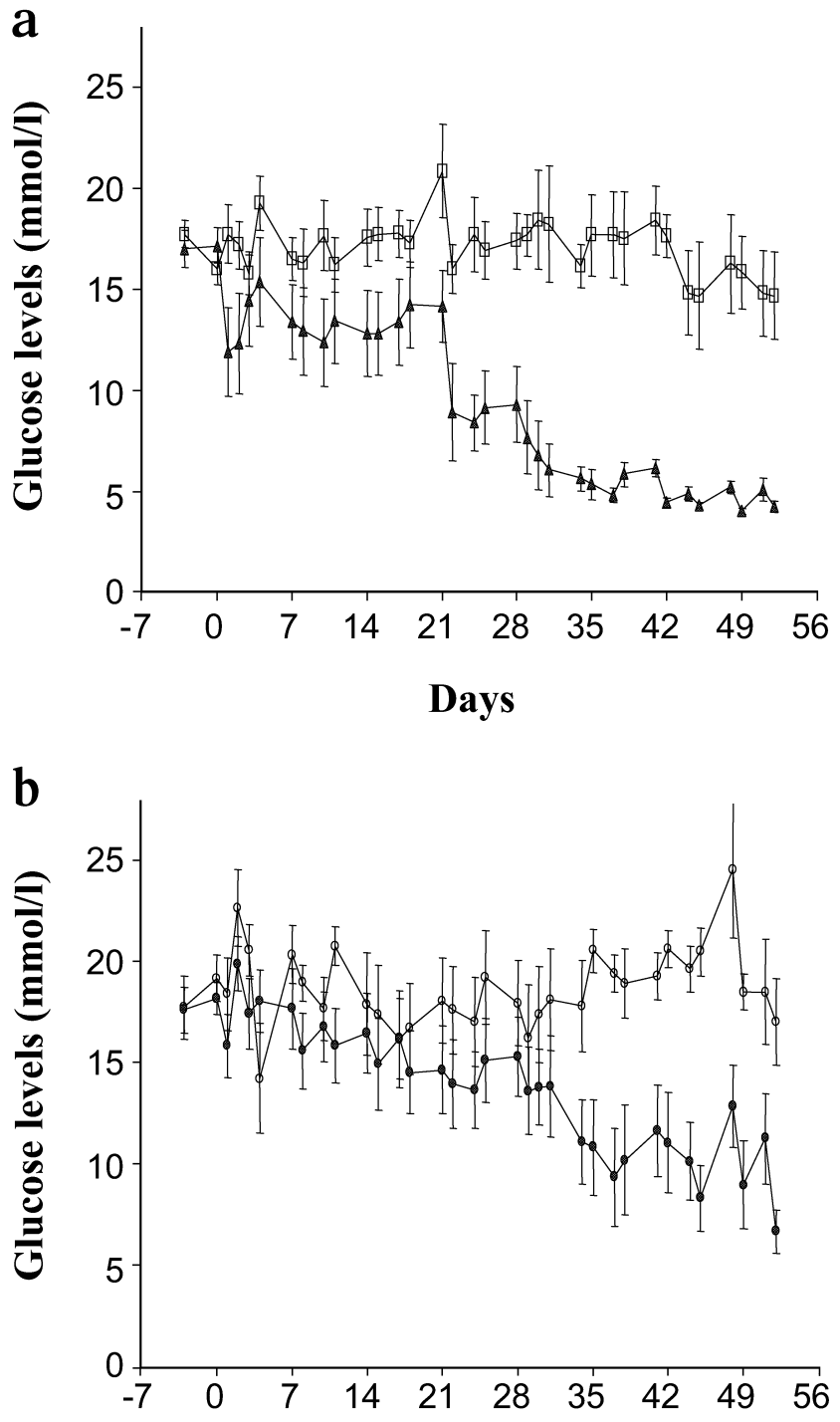

\section{Days}

Fig. 4. Effect of different KRX-683 ${ }_{124}$ dosing regimens on glucose levels in diabetic Psammomys. a. Animals received either KRX-683 ${ }_{124}, 12.5 \mathrm{mg} / \mathrm{kg}$ weekly, for 7 weeks (filled triangles, $n=11$ ) or vehicle control (open squares, $n=11$ ). b. Psammomys treated either with KRX-683 $124,6.25 \mathrm{mg} / \mathrm{kg}$ twice weekly, for 7 weeks (filled circles) or with vehicle (open circles)

heterogeneous, the percent increase in glucose for each animal during the trial was assessed. The nonfasting blood glucose levels of the KRX- $683_{124}$ treatment group was $31 \%$ lower than the control group $(p \leq 0.048) 30$ days after treatment began. Howerver, no acute drop to normal occurred as in Psammomys (Fig. 2b). Animal weights at the end of the protocol did not differ between the treated and untreated group (data not shown), suggesting that the improvement in blood glucose was not related to decreased food intake or altered metabolic rates. In contrast to Psammomys, there was also no change in the superscapular fat pad between treated and non-treated ZDF rats (Table 3 ).
Other parameters related to diabetes also changed after administration of KRX-683 124 . There was a significant reduction in fasting triglyceride levels after 4 weeks of KRX-683 124 treatment, compared with the control group $(4.9 \pm 0.6$ vs $6.4 \pm 0.4 \mathrm{mmol} / 1 \mathrm{respec}-$ tively, $p \leq 0.012$ ) (Fig. 5b). Both fasting and the 3 -h blood glucose levels after glucose tolerance tests were significantly lower in the KRX-683 124 animals $(38 \%$ for fasting blood glucose, $p \leq 0.028 ; 30 \%, p \leq 0.027$, for the 3-h post-glucose tolerance tests) (Fig. 5c).

KRX-683 124 improves fasting and post-prandial glucose levels in hyperglycaemic $d b / d b$ mice. KRX$683_{124}$ was also tested in $d b / d b$ mice receiving $20 \mathrm{mg} / \mathrm{kg}$ of KRX-683 124 for 5 weeks. While there was no difference in random non-fasting blood glucose levels between KRX-683 124 -treated and vehicletreated animals, there were significant differences between the two groups in the glucose tolerance tests. Both the fasting $(4.0 \pm 0.2$ vs $5.9 \pm 0.5 \mathrm{mmol} / 1$ respectively, $p \leq 0.001)$ and 2 -h blood glucose levels $(9.2 \pm 1.2$ vs $17.0 \pm 1.4 \mathrm{mmol} / 1, p \leq 0.0004)$ were lower in the KRX-683 ${ }_{124}$-treated animals (Fig. 6). As with the ZDF rats, KRX-683 124 had no effect on the overall weight gain or the epididymal fat pad mass of these mice (Table 3).

\section{Discussion}

Overview. We evaluated the physiological effect of short peptides derived from GRK2/3 on glucose homeostasis. The rationale for using GRK2/3-derived peptides is that this kinase is involved in multiple metabolic processes including those involved in energy balance. These peptides could potentially modulate the activity of GRK $2 / 3$ by interfering with kinase-substrate interactions. Two of the peptides, KRX-683 107 and KRX-683 124 , were shown to stimulate the allegedly GRK-controlled response of melanogenesis, in a defined cell-based assay, via a PKC-dependent pathway. In three models of Type 2 diabetes the two KRX683 peptides fully or partially reversed the diabetic phenotype in most of the treated subjects, reducing non-fasting blood glucose levels and improving insulin and triglyceride levels associated with Type 2 diabetes.

Role of GRK2/3 in glucose homeostasis. The GRK family of protein kinases plays an important role in regulating the activity of GPCRs. GRK2 and GRK3 regulate the activity of numerous GPCRs primarily by uncoupling the receptor from its associated $G$ proteins. These kinases phosphorylate the serine/threonine located within the cytosolic carboxy terminal portion of GPCRs, when the latter are in their active conformation [25]. The role of GRK2 in pathophysiological processes such as congestive heart failure and 
$\mathbf{a}$
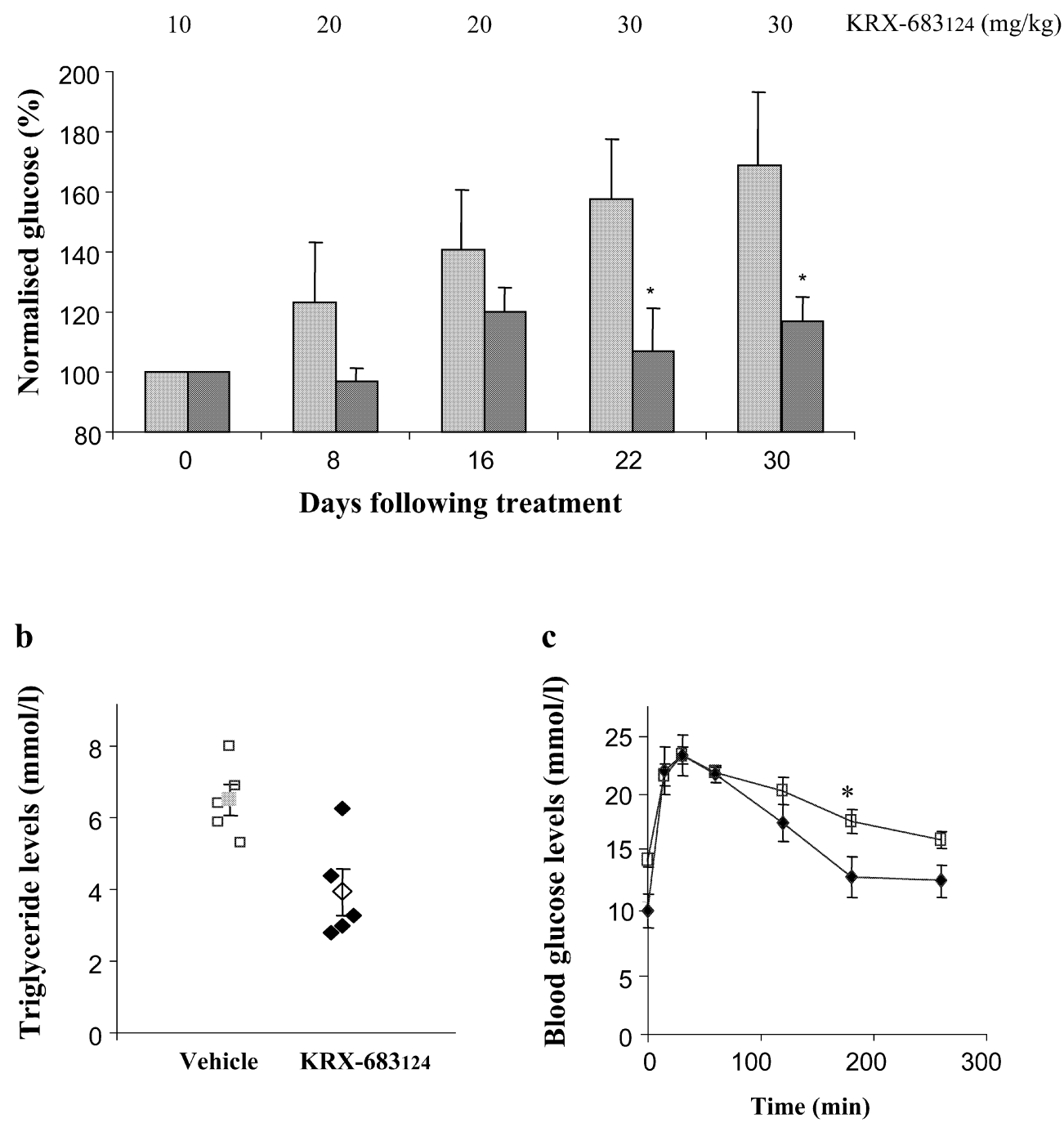

Fig. 5. Antidiabetic effect of KRX-683 124 in Zucker diabetic fatty (ZDF) rats. a. Reduced fed glucose levels in ZDF rats treated with increasing doses of KRX-683 $3_{124}$ for 1 month vs vehicletreated control rats. Glucose normalisation is based on pre-treat-

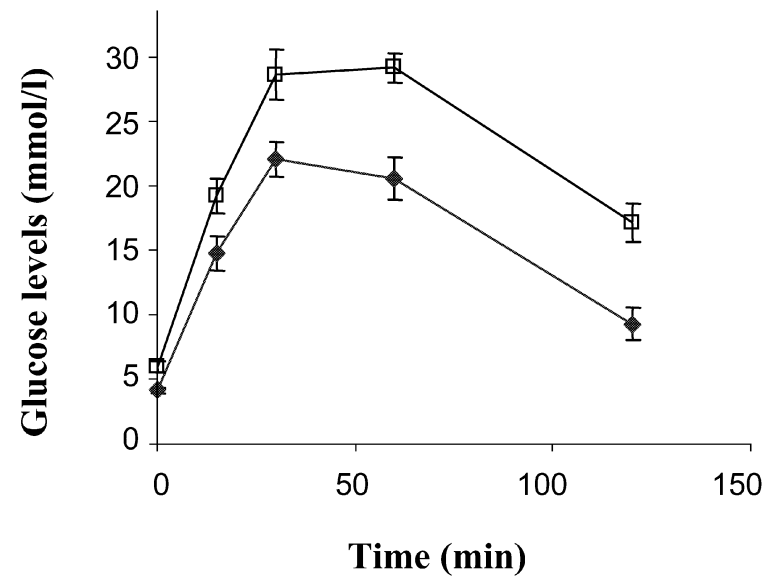

Fig. 6. Effect of KRX-683 124 on fasting and 3-h glucose tolerance tests in $d b / d b$ mice which received KRX-683 124 , $20 \mathrm{mg} / \mathrm{kg}$ weekly, for 5 weeks (filled diamond) or vehicle control (open square)

ment levels (see text). b. Triglyceride levels after 30 days of treatment. KRX-683 124 treatment (filled diamonds); control animals (open squares). c. Glucose tolerance tests curves of treated (filled diamonds) and control animals (open squares)

hypertension has been identified [11]. In the heart, upregulation of GRK2 contributes to heart failure which is reversible when GRK2 is inhibited [17]. In mice lacking GRK3, airway smooth muscle were hyperresponsive to cholinergic agonists and baroreflexinduced tachycardia was accentuated [26].

The role of GRK2 and GRK3 in glucose homeostasis has not been extensively studied. It is known that the $\beta 2$-adrenergic receptor is down-regulated by GRK2 and this receptor subtype has a significant role in regulating lipid metabolism in adipocytes [27, 28, 29 ]. In people with insulin resistance, there is a decrease in lipolysis due to a reduction in $\beta 2$-adrenergic receptor in fat cells. Alterations in the function of $\beta 2$-adrenergic receptor correlated with glucose intolerance and insulin resistance [30]. Polymorphisms located within $\beta 2$-adrenergic receptor have been associ- 
ated with obesity in various ethnic groups [31]. One mutation known to decrease receptor density and efficiency is Arg16Gly, which is associated with longitudinal increases in weight gain in a large cohort of male children [32]. In other studies, the same mutation has been associated with a greater relative risk for developing Type 2 diabetes [33]. The alteration in fatty acid metabolism associated with polymorphisms of the $\beta 2$-adrenergic receptor makes this gene a possible "thrifty gene" candidate. One of the fundamental tenets of the "thrifty gene" hypothesis is that in energy-poor environments, organisms that have a lower threshold for insulin secretion and a lower capacity for insulin clearance and are therefore more efficient in storing fat will have a greater chance of survival. These advantages turn into a disadvantage in energyrich environments, in which excess lipogenesis leads to insulin resistance and Type 2 diabetes [34, 35].

GRK2 may also regulate appetite and regulators of fat metabolism. In the central nervous system, $\alpha-\mathrm{MSH}$, via its interaction with MCR-4, has an anorectic effect and regulates insulin secretion in response to glucose levels. When the interaction between $\alpha-\mathrm{MSH}$ and MCR-4 is blocked, as occurs in the agouti mouse phenotype, the animals have obesity and glucose intolerance [36]. The same phenotype is also seen in the MCR-4 knock-out model [37]. A recent study has shown that GRK2 is one of the mediators of MCR-4 desensitisation. This study also suggested that abnormally elevated MCR-4 desensitisation by GRK2 may be associated with obesity and appetite dysregulation [16].

Sequence-based inhibition of GRK2/3. A method for modulating the activity of a protein kinase is to use peptides that contain sequences that are identical or complementary to specific regions within the target protein $[38,39,40]$. The presumed mechanism of action of these sequence-based peptides is to interfere with the interaction between the kinase and its specific substrate [19]. In the case of GRK2, relatively long peptides complementary to the $\mathrm{C}$ terminus of the kinase have been successfully introduced into myocytes using viral vectors containing DNA sequences encoding for the peptide. This peptide inhibits the endogenous activity of GRK2 and reverses GRK2mediated heart failure [41]. To avoid the need for a relatively long peptide or the requirement of transfection, we developed an alternative approach of coupling fatty acid moieties to short synthetic peptides derived from the HJ-loop of GRK2/3, a kinasesubstrate interaction site that has been identified in protein kinases [19].

To test efficacy of specific peptides derived from the HJ loop of GRK2/3, a melanogenesis assay was used. Melanogenesis is mediated by GPCRs, including MCR-1 and endothelin-1 receptors [42, 43]. The endothelin receptor is known to be regulated by
GRK2, and at least two of the closely related MCRs (MCR-2, MCR-4) are modulated by phosphorylation mediated by GRK2 [15, 16, 44]. In addition, PKC, which also plays a role in melanogenesis, is inactivated by GRK2 in specific tissues [45]. KRX-683 124 stimulated melanin production in the absence of either $\alpha$-MSH or endothelin in the culture media. In the presence of $\alpha-\mathrm{MSH}$, the effects of KRX-683 124 were additive. Both the effect of KRX-683 124 and $\alpha-\mathrm{MSH}$ on melanogenesis were abolished when a PKC inhibitor, GF109203X, was added, suggesting that KRX-683 acts upstream to PKC in terms of its effects on melanogenesis. It is probable that KRX-683 124 disturbs the interaction of GRK2 with PKC, thereby attenuating the inhibitory effect of GRK2 on PKCmediated melanogenesis. Alternatively, KRX-683 124 may enhance the basal activation of the endothelin and MCR receptors by blocking their interaction with GRK.

In vivo effects of GRK2/3 inhibition. The nutritionally induced diabetes in Psammomys obesus is analogous to forms of Type 2 diabetes seen in several human population groups such as the Native American Pima Indians and the Australian Aborigines [22]. The course of diabetes in those animals is characterised by an initial stage of hyperinsulinaemia, followed by hyperinsulinaemic hyperglycaemia and a hypoinsulinaemic phase associated with ketosis and ultimate death. Diabetes evolving after provision of a highenergy diet in Psammomys has been associated with the "thrifty metabolism" which utilises innate insulin resistance to survive in a nutrient-poor desert environment. Treatment of Psammomys with KRX-683 resulted in a reduction of non-fasting blood glucose and insulin levels, and also of weight (fat pad and total animal mass). The fact that both insulin levels and fat pad were reduced suggests that the mechanism of action of KRX-683 is to increase insulin sensitivity leading to enhanced glucose uptake by muscle, and reduced lipogenesis in adipocytes. Such an effect would be consistent with up-regulation of $\beta 2$-adrenergic receptor which induces lipolysis and reduces insulin resistance.

The antidiabetic effect of the two KRX-683 peptides could be non-specific, related to a non-selective appetite suppression. Such an effect would be consistent with the lower weight of the Psammomys. However, if the effect of the drug was only on appetite, organ weight, e.g. the heart, would also be expected to be reduced in ZDF rats and $d b / d b$ mice. This was not the case, for no such weight loss was seen in ZDF rats or $d b / d b$ mice. In addition, related peptides of a similar size had no effect on glucose homeostasis or weight, suggesting that the effect of the KRX-683 peptides were sequence-specific.

The lack of response in some of the Psammomys animals to the KRX-683 peptide raises the issue of in- 
dividual animal sensitivity to the effects of the drug, which occurred with all compounds tested. As Psammomys are not a completely uniform population, it is possible that the level of insulin resistance varied among animals, and that some animals would require higher doses of the drug for an overt effect. Similarly, some of the Psammomys may have progressed further towards developing hypoinsulinaemic hyperglycaemia, and KRX-683 would not be expected to have an effect on glucose homeostasis in the absence of endogenous insulin. In this regard, further studies are necessary to determine the dose-response effect of KRX-683 as it relates to the level of insulin resistance and the endogenous insulin reserve.

Recently, it has been found that diabetes prone Psammomys overexpress PKC- $\varepsilon$ even before the onset of overt hyperglycaemia [46]. PKC- $\varepsilon$, which is activated by diacylglycerols, is associated with muscle insulin resistance in several models of Type 2 diabetes, and it has been postulated that both the high glucose and high triglyceride levels contribute to the activation of this PKC isoenzyme [47]. Even in the pre-diabetic stage there are physiological alterations in energy metabolism that are unique to the Psammomys ("thrifty-gene" hypothesis) and that cause a rise in PKC- $\varepsilon$ when these animals are provided with a caloric load inappropriate for their metabolic capacity [21, 46].

KRX-683 also had an antidiabetic effect on the ZDF and $d b / d b$ models of diabetes. In the case of ZDF rats, treatment with KRX-683 124 resulted in a lowering of fasting and post-prandial blood glucose, associated with reduced triglyceride levels. However, animal weight in these hyperphagic animals was not reduced. It should be noted that the glucose response in these genetic mutants was not as impressive as in the Psammomys, and the glucose levels did not return to normal. Possible explanations for this may be related to the natural history of diabetes in these animals. Like the Psammomys, these animals experience beta cell apoptosis which is mediated by elevated lipid and/or glucose levels [46, 48]. In the experiments described above, it is possible that extensive apoptosis had already occurred, so that even though triglyceride levels improved markedly, damage to the pancreas was already considerable. Such a phenomenon was also described in ZDF rats treated with the peroxisome proliferator-activated receptor- $\gamma$ agonist, rosiglitazone, which did not reverse diabetes in ZDF rats with established hyperglycaemia, but did prevent progression from insulin resistance to overt diabetes [49]. Thus, it may be necessary to initiate treatment with KRX-683 at an earlier stage, before the start of the high-energy diet.

KRX-683 124 's antidiabetic effect in $d b / d b$ mice is demonstrated by an improved glucose tolerance tests profile (Fig. 6). In the $d b / d b$ model of diabetes, the genetic defect is associated with a mutation in the leptin receptor [50]. These animals have severe insulin resistance, which is accompanied by insulin hypersecretion leading to obesity. Interestingly, KRX-683 partially reversed the diabetic phenotype induced by a defect in leptin-stimulated signal transduction. One possibility is that KRX-683 compensates for the loss of leptinmediated stimulation of central MCRs that control both satiety and insulin secretion in response to glucose levels. However, there was no weight difference between the groups treated with KRX-683 and control groups treated with vehicle, which would be expected if KRX-683 did exert an effect on melanocortin-stimulated anorexia. It is more likely that KRX-683 affects insulin-mediated glucose uptake without affecting appetite or caloric intake.

Conclusion. Small peptides based on the kinase-substrate interaction site in GRK2/3 have an anti-diabetogenic effect in three different animal models of diabetes. The data presented suggest that GRK2/3 plays a significant role in glucose homeostasis, and modulation of this kinase can partially reverse the diabetic phenotype. Further research will determine the exact mechanism by which KRX-683 peptides inhibit GRK2/3, and also identify the specific GRK2/3-mediated pathways that regulate glucose metabolism.

Acknowledgements. Y. Anis and O. Leshem contributed equally to this research.

Statement by the authors:

For purposes of disclosure, we would like to make the following statement regarding any potential conflict of interests. The work reported in this manuscript was funded in part by Keryx Biopharmaceuticals. Professor Samuel Ben-Sasson served as the Chief Scientific Officer in the past, and has a financial interest in the company. Dr. Morris Laster was the Chief Executive Officer of Keryx Biopharmaceuticals until 2003, and has a financial interest in the company. Dr. Hadas Reuveni is a current employee of Keryx Biopharmaceuticals and has a financial interest in the company. Dr. Yossi Anis, Orit Leshem, Dr. Barak Yahalom and Dr. Ishaiah Wexler are previous employees of Kerys Biopharmaceuticals, and currently have no financial interest in the company. Professors Ehud Ziv, Eleazar Shafrir and Itamar Raz, as well as Rivka-Ben-Sasson have no financial interest in Keryx Biopharmaceuticals.

\section{References}

1. Groop L, Orho-Melander M (2001) The dysmetabolic syndrome. J Intern Med 250:105-120

2. McIntyre EA, Walker M (2002) Genetics of type 2 diabetes and insulin resistance: knowledge from human studies. Clin Endocrinol (Oxf) 57:303-311

3. Gloyn AL, McCarthy MI (2001) The genetics of type 2 diabetes. Best Pract Res Clin Endocrinol Metab 15:293-308

4. Moneva MH, Dagogo-Jack S (2002) Multiple drug targets in the management of type 2 diabetes. Curr Drug Targets $3: 203-221$

5. Philipson LH (2002) Beta-agonists and metabolism. J Allergy Clin Immunol 110:S313-S317 
6. Crowley VE, Yeo GS, O'Rahilly S (2002) Obesity therapy: altering the energy intake-and-expenditure balance sheet. Nat Rev Drug Discov 1:276-286

7. Yamada K, Ishiyama-Shigemoto S, Ichikawa $\mathrm{F}$ et al. (1999) Polymorphism in the $5^{\prime}$-leader cistron of the beta2adrenergic receptor gene associated with obesity and type 2 diabetes. J Clin Endocrinol Metab 84:1754-1757

8. Ishiyama-Shigemoto S, Yamada K, Yuan X, Ichikawa F, Nonaka K (1999) Association of polymorphisms in the beta2-adrenergic receptor gene with obesity, hypertriglyceridaemia, and diabetes mellitus. Diabetologia 42:98-101

9. Tseng CC, Zhang XY (2000) Role of G protein-coupled receptor kinases in glucose-dependent insulinotropic polypeptide receptor signaling. Endocrinology 141:947-952

10. Muzumdar R, Ma X, Yang X et al. (2003) Physiologic effect of leptin on insulin secretion is mediated mainly through central mechanisms. FASEB J 17:1130-1132

11. Pitcher JA, Freedman NJ, Lefkowitz RJ (1998) G proteincoupled receptor kinases. Annu Rev Biochem 67:653-692

12. Aragay AM, Ruiz-Gomez A, Penela P et al. (1998) G protein-coupled receptor kinase 2 (GRK2): mechanisms of regulation and physiological functions. FEBS Lett 430:3740

13. Lefkowitz RJ (1996) G protein-coupled receptors and receptor kinases: from molecular biology to potential therapeutic applications. Nat Biotechnol 14:283-286

14. Fredericks ZL, Pitcher JA, Lefkowitz RJ (1996) Identification of the $G$ protein-coupled receptor kinase phosphorylation sites in the human beta2-adrenergic receptor. J Biol Chem 271:13796-13803

15. Freedman NJ, Ament AS, Oppermann M, Stoffel RH, Exum ST, Lefkowitz RJ (1997) Phosphorylation and desensitization of human endothelin A and B receptors. Evidence for $G$ protein-coupled receptor kinase specificity. J Biol Chem 272:17734-17743

16. Shinyama H, Masuzaki H, Fang H, Flier JS (2003) Regulation of melanocortin-4 receptor signaling: agonist-mediated desensitization and internalization. Endocrinology 144:13011314

17. Eckhart AD, Koch WJ (2001) Transgenic studies of cardiac adrenergic receptor regulation. J Pharmacol Exp Ther 299:1-5

18. Spurney RF, Flannery PJ, Garner SC et al. (2002) Anabolic effects of a $G$ protein-coupled receptor kinase inhibitor expressed in osteoblasts. J Clin Invest 109:1361-1371

19. Niv MY, Rubin H, Cohen J et al. (2004) Sequence-based design of kinase inhibitors applicable for therapeutics and target identification. J Biol Chem 279:1242-1255

20. Briles EB, Kornfeld S (1978) Isolation and metastatic properties of detachment variants of B16 melanoma cells. J Natl Cancer Inst 60:1217-1222

21. Shafrir E, Ziv E (1998) Cellular mechanism of nutritionally induced insulin resistance: the desert rodent Psammomys obesus and other animals in which insulin resistance leads to detrimental outcome. J Basic Clin Physiol Pharmacol 9:347-385

22. Kalman R, Ziv E, Shafrir E, Bar-On H, Perez R (2001) Psammomys obesus and the albino rat-two different models of nutritional insulin resistance, representing two different types of human populations. Lab Anim 35:346-352

23. Etgen GJ, Oldham BA (2000) Profiling of Zucker diabetic fatty rats in their progression to the overt diabetic state. Metabolism 49:684-688

24. Kobayashi K, Forte TM, Taniguchi S, Ishida BY, Oka K, Chan L (2000) The db/db mouse, a model for diabetic dyslipidemia: molecular characterization and effects of Western diet feeding. Metabolism 49:22-31
25. Lodowski DT, Pitcher JA, Capel WD, Lefkowitz RJ, Tesmer JJ (2003) Keeping G proteins at bay: a complex between $\mathrm{G}$ protein-coupled receptor kinase 2 and Gbetagamma. Science 300:1256-1262

26. Walker JK, Peppel K, Lefkowitz RJ, Caron MG, Fisher JT (1999) Altered airway and cardiac responses in mice lacking $\mathrm{G}$ protein-coupled receptor kinase 3. Am J Physiol 276:R1214-R1221

27. Benovic JL, Mayor F Jr, Staniszewski C, Lefkowitz RJ, Caron MG (1987) Purification and characterization of the beta-adrenergic receptor kinase. J Biol Chem 262:90269032

28. Rasmussen M, Almdal T, Bratholm P, Christensen NJ (2003) Elevated beta2-adrenoceptor protein concentration in adipose tissue from obese subjects is closely related to the body mass index and waist/hip ratio. Clin Sci (Lond) 104:93-102

29. Hupfeld CJ, Dalle S, Olefsky JM (2003) Beta-Arrestin 1 down-regulation after insulin treatment is associated with supersensitization of beta 2 adrenergic receptor Galpha s signaling in 3T3-L1 adipocytes. Proc Natl Acad Sci USA 100:161-166

30. Reynisdottir S, Ellerfeldt K, Wahrenberg H, Lithell H, Arner P (1994) Multiple lipolysis defects in the insulin resistance (metabolic) syndrome. J Clin Invest 93:25902599

31. Large V, Hellstrom L, Reynisdottir S et al. (1997) Human beta-2 adrenoceptor gene polymorphisms are highly frequent in obesity and associate with altered adipocyte beta- 2 adrenoceptor function. J Clin Invest 100:3005-3013

32. Ellsworth DL, Coady SA, Chen W et al. (2002) Influence of the beta2-adrenergic receptor Arg16Gly polymorphism on longitudinal changes in obesity from childhood through young adulthood in a biracial cohort: the Bogalusa Heart Study. Int J Obes Relat Metab Disord 26:928-937

33. Chang TJ, Tsai MH, Jiang YD et al. (2002) The Arg16Gly polymorphism of human beta2-adrenoreceptor is associated with type 2 diabetes in Taiwanese people. Clin Endocrinol (Oxf) 57:685-690

34. Joffe B, Zimmet P (1998) The thrifty genotype in type 2 diabetes: an unfinished symphony moving to its finale? Endocrine 9:139-141

35. Groop LC (1999) Insulin resistance: the fundamental trigger of type 2 diabetes. Diabetes Obes Metab 1 [Suppl 1]: S1-S7

36. Goodfellow VS, Saunders J (2003) The melanocortin system and its role in obesity and cachexia. Curr Top Med Chem 3:855-883

37. Butler AA, Cone RD (2002) The melanocortin receptors: lessons from knockout models. Neuropeptides 36:77-84

38. Zaliani A, Pinori M, Ball HL, DiGregorio G, Cremonesi P, Mascagni P (1998) The interaction of myristylated peptides with the catalytic domain of protein kinase $\mathrm{C}$ revealed by their sequence palindromy and the identification of a myristyl binding site. Protein Eng 11:803-810

39. Gould C, Wong CF (2002) Designing specific protein kinase inhibitors: insights from computer simulations and comparative sequence/structure analysis. Pharmacol Ther 93:169-178

40. Licht T, Tsirulnikov L, Reuveni H, Yarnitzky T, Ben Sasson SA (2003) Induction of pro-angiogenic signaling by a synthetic peptide derived from the second intracellular loop of S1P3 (EDG3). Blood 102:2099-2107

41. Koch WJ, Hawes BE, Inglese J, Luttrell LM, Lefkowitz RJ (1994) Cellular expression of the carboxyl terminus of a G protein-coupled receptor kinase attenuates $\mathrm{G}$ beta gammamediated signaling. J Biol Chem 269:6193-6197 
42. Kadekaro AL, Kanto H, Kavanagh R, Abdel-Malek ZA (2003) Significance of the melanocortin 1 receptor in regulating human melanocyte pigmentation, proliferation, and survival. Ann NY Acad Sci 994:359-365

43. Imokawa G, Kobayashi T, Miyagishi M, Higashi K, Yada Y (1997) The role of endothelin-1 in epidermal hyperpigmentation and signaling mechanisms of mitogenesis and melanogenesis. Pigment Cell Res 10:218-228

44. Baig AH, Swords FM, Szaszak M, King PJ, Hunyady L, Clark AJ (2002) Agonist activated adrenocorticotropin receptor internalizes via a clathrin-mediated $\mathrm{G}$ protein receptor kinase dependent mechanism. Endocr Res 28:281-289

45. Ji S, Liu X, Li S et al. (2003) Ph domain of g protein-coupled receptor kinase- 2 binds to protein kinase $C(\mathrm{pkc})$ and negatively regulates activity of pkc kinase. Front Biosci 8:A34-A39

46. Shafrir E (2001) Albert Renold memorial lecture: molecular background of nutritionally induced insulin resistance leading to type 2 diabetes - from animal models to humans. Int J Exp Diabetes Res 2:299-319

47. Idris I, Gray S, Donnelly R (2001) Protein kinase C activation: isozyme-specific effects on metabolism and cardiovascular complications in diabetes. Diabetologia 44:659673

48. Unger RH, Orci L (2001) Diseases of liporegulation: new perspective on obesity and related disorders. FASEB J 15:312-321

49. Hirshman MF, Fagnant PM, Horton ED, King PA, Horton ES (1995) Pioglitazone treatment for 7 days failed to correct the defect in glucose transport and glucose transporter translocation in obese Zucker rat (fa/fa) skeletal muscle membranes. Biochem Biophys Res Commun 208:835-845

50. Chen H, Charlat O, Tartaglia LA et al. (1996) Evidence that the diabetes gene encodes the leptin receptor: identification of a mutation in the leptin receptor gene in $\mathrm{db} / \mathrm{db}$ mice. Cell 84:491-495 